\title{
EFFECT OF SOIL MOISTURE DEPLETION AND NITROGEN LEVELS ON WHEAT (Triticum aestivum L.). \\ El-Agrodi, M.W.M. ${ }^{1}$; M.M. Saeid ${ }^{2}$; G. L. Ahmed ${ }^{1}$ and T.S.H. Khalifa ${ }^{2}$ \\ 1- Soil Dept. Fac. of Agric., Mansoura Univ., Egypt. \\ 2- Soil, Water and Environment Res. Inst., A.R.C., Egypt.
}

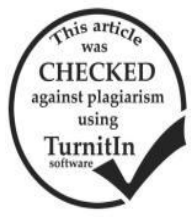

\begin{abstract}
Lysimeter experiment was conducted during winter season of 2013-2014 and 2014-2015 in Sakha Agricultural Research Station Farm; Kafr El-Sheikh Governorate. This study aimed to clarify the effect of soil moisture depletion (45, 60 and 75\% from the available water) and nitrogen levels (zero, 75, 100 and 125\% from the recommended dose) as well as their interaction on wheat yield, water and nitrogen use efficiencies.

The obtained results can be summarized in;

- Soil moisture depletion and nitrogen fertilizer levels interaction high significantly affected grain yield in both seasons. The highest values of grain yield (2889.60 and $2829.40 \mathrm{~kg} \mathrm{fed}^{-1}$ in the $1^{\text {st }}$ and $2^{\text {nd }}$ season, respectively) were realized by applying the treatment of irrigation after depletion $45 \%$ from available water $+125 \%$ of $\mathrm{N}$ recommended dose.

- The highest values of wheat straw yield (3355.19 and $3297 \mathrm{~kg} \mathrm{fed}^{-1}$ ) were obtained under irrigation after depletion $45 \%$ from available water in the first and second season, respectively. Also the different $\mathrm{N}$ rates (control, $75 \%, 100 \%$ and $125 \%$ of $\mathrm{N}$ recommended dose) high significantly affected straw yield. The straw yield increased by $22.46 \%$ at $\mathrm{N}_{75 \%}, 31.61 \%$ at $\mathrm{N}_{100 \%}$ and $43.39 \%$ at $\mathrm{N}_{125 \%}$ in first season and by $\left(18.71 \%\right.$ at $\mathrm{N}_{75 \%}, 24.79 \%$ at $\mathrm{N}_{100 \%}$ and $26.26 \%$ at $\left.\mathrm{N}_{125 \%}\right)$ in second season, as compared to control.

- The highest value of nitrogen agronomic efficiency (NAE) was obtained due to the irrigation after depletion $45 \%$ from available water $+75 \%$ of $\mathrm{N}$ recommended dose. The lowest value of NAE was achieved due to the irrigation after depletion $75 \%$ from available water $+125 \%$ of $\mathrm{N}$ recommended dose.

- Apparent nitrogen recovery by wheat was high significantly affected by the interaction between soil moisture depletion and nitrogen fertilizer levels in both seasons. The highest values of apparent nitrogen recovery by wheat were realized by applying the treatment of irrigation after depletion $45 \%$ from available water $+75 \%$ of $\mathrm{N}$ recommended dose for both seasons.

- The highest and lowest values of water use efficiency were obtained from treatments of irrigation after depletion $45 \%$ from available water and $75 \%$ from $\mathrm{N}$ recommended dose and irrigation after depletion $75 \%$ from available water without addition of nitrogen fertilizer in both growing seasons, respectively.
\end{abstract}

Keywords: Wheat, nitrogen agronomic efficiency, apparent nitrogen recovery, soil moisture depletion, field water use efficiency.

\section{INTRODUCTION}

The domestic wheat production in 2013 season was estimated by 8.7 million tons, whereas the Egyptian national consumption of wheat was about 17.7 million tons in 2013; there is a great gab between the consumption and production. Egypt imports above five million tons of wheat grains. Unless domestic wheat production increases annually, the deficit will increase due to the increase of population rate $(2 \%)$ and present consumption per capita estimated by about $200 \mathrm{~kg}$ year ${ }^{1}$ (USDA, 2013).

Recently, water scarcity became an alarming problem. Water stress may result in similar yield or low yield reduction, with the benefit that the amount of saved irrigation water can be assigned to be used in irrigating new lands. However, water is an affecting factor in any agricultural expansion. Accordingly, it is advised to evaluate possible new approaches to control the crop water requirements through modern irrigation systems and management techniques. So, the use of improved irrigation systems becomes very important to save water, give favorable crop yield, optimum use of water and minimum labors requirements. Many researchers proved the importance of irrigation treatment to maximize wheat productivity. In this respect, Beshara (2012) stated that the highest value of the grain, straw, total $\mathrm{N}$ uptake and WUE were obtained with $40 \%$ depletion of available soil moisture in the growing season. While the lowest value of these traits were obtained with $70 \%$ depletion of available soil moisture in both seasons. Hammad- Salwa and Ali (2014) indicated that delaying irrigation until $65 \%$ or $80 \%$ depletion decreased grain and straw yields. Increasing soil moisture depletion levels decreased the grain and straw yields compared with $50 \%$ depletion of the two seasons. They found also that total $\mathrm{N}$ uptake by wheat went as the same trend of grain and straw yields. Mahamed et al., (2011) suggested that the greatest water use efficiency was observed when irrigation schedule applied when $50 \%$ of the available soil water is depleted as compared with Irrigation was applied when the soil moisture was depleted by $60 \%$ and $75 \%$ of available soil water (ASW)

Egypt utilizes fertilizers at an accelerating rate, due to various factors such as the increase in the cropped area and raising the rate of fertilizer application for various crops. Consequently, Egypt is considered to be a heavy user of chemical fertilizers, especially $\mathrm{N}$ fertilizers then $\mathrm{P}$ and $\mathrm{K}$ fertilizers. Soil fertility continues to decline because of combined effects of increasing pressure for land use for crop production, inadequate compensation of nutrients exported and lack of nutrients management. Gazia and Abd EL Aziz (2013) concluded that increasing $\mathrm{N}$ level up to $90 \mathrm{~kg}$ $\mathrm{fed}^{-1}$ led to a significant increase in wheat grain yield. Mosaad et al., (2013) showed that wheat grain and straw yields and $\mathrm{N}$-uptake by grain and straw increased with use of mineral fertilizer rates up to $90 \mathrm{~kg} \mathrm{~N} \mathrm{fed}^{-1}$, but $\mathrm{N}$ utilization efficiency for wheat crop was decreased. Rahman et al., (2011) reported that apparent nitrogen use efficiency (NUE) in terms of amount grain 
production per unit $\mathrm{N}$ applied significantly decreased with the increasing $\mathrm{N}$ rate. Under the sub-optimum rate of $80 \mathrm{~kg} \mathrm{~N} \mathrm{ha}^{-1}$ application of all basal gave the maximum NUE, where minimum NUE was obtained under $\mathrm{N}$ rate of $\left(120 \mathrm{~kg} \mathrm{ha}^{-1}\right)$. Also they found that the highest values for total nitrogen uptake were achieved with $\mathrm{N}$ rate of $\left(120 \mathrm{~kg} \mathrm{ha}^{-1}\right)$. Noureldin et al., (2013) reported that supplying wheat plants by $50 \mathrm{~kg} \mathrm{~N}^{-1}$ produced the maximum grain yield/ $\mathrm{N}$ unit and the greatest apparent nitrogen use efficiency (AE). They also found that low apparent nitrogen use efficiency (AE) was achieved due to adding $100 \mathrm{~kg} \mathrm{~N}^{-1}$. ElGizawy (2005) indicated that grain yield fed $^{-1}$ was increased due to increasing the rates of $\mathrm{N}$ from 50 to 75 and $100 \mathrm{~kg} \mathrm{~N} \mathrm{fed}^{-1}$ in both season. Faizy et al., (2010) stated that nitrogen use efficiency (NUE) and nitrogen recovery of wheat yield decreased with increasing $\mathrm{N}$ level up to $140 \mathrm{~kg} \mathrm{fed}^{-1}$, where the highest value of NUE and nitrogen recovery obtained with $40 \mathrm{~kg} \mathrm{~N}^{-1} \mathrm{fed}^{-1}$ as compared with $140 \mathrm{~kg} \mathrm{~N} \mathrm{fed}{ }^{-1}$. Haile et al., (2012) reported that the highest $\mathrm{N}$ uptake efficiencies were recorded at $30 \mathrm{~kg} \mathrm{~N}^{-1}$ and the lowest $\mathrm{N}$ uptake efficiencies were recorded at the highest $\mathrm{N}$ rate $(120 \mathrm{~kg}$ $\mathrm{N} \mathrm{ha}^{-1}$ ).

Therefore, the objective of this study is to evaluate the effect of soil moisture depletion levels and different nitrogen rates on wheat plant.

\section{MATERIALS AND METHODS}

Lysimeter experiment was conducted at Sakha Agricultural Research Station Farm; Kafr El-Sheikh Governorate, North-Nile Delta. The study aimed to clarify the effect of different soil moisture depletion, nitrogen fertilization and their interaction on wheat yield, water and nitrogen use efficiencies.

The studied factors were three soil moisture depletion (irrigation after depletion $45 \%, 60 \%$ and $75 \%$ from available water) and four nitrogen fertilization levels $(0,75,100$ and $125 \%$ of nitrogen recommended dose of Agric. Ministry). The experiment was conducted in split plot design, with three replicates.
Lysimeter $\left(0.78 \mathrm{~m}^{2}\right)$ was divided into 3 groups; each group includes 12 lysimeters to be studied.

Lysimeter was a circular shape; the diameter of one metre and a height of $60 \mathrm{~cm}$ with filter (sand and gravel) of $10 \mathrm{~cm}$, each lysimeter was filled by $458.25 \mathrm{~kg}$ of the clay soil. The area of Lysimeter was determined using the formula: Area $=\pi \times r^{2}$. Nitrogen recommendation for wheat $75 \mathrm{~kg} \mathrm{~N}$ fed ${ }^{-1}$. Urea fertilizer was used as a source of nitrogen

Wheat (Triticum aestivum L.) variety (Sakha 93) was sown in first season on December, $5^{\text {th }}, 2013$ and the second season was sown on December, $3^{\text {rd }}, 2014$. Harvesting was done on May, 20 ${ }^{\text {th }}, 2014$ and on May, $18^{\text {th }}, 2015$ after full maturity for both seasons. The wheat was sown at the rate of $60 \mathrm{~kg}$ of seeds $\mathrm{fed}^{-1}$. Each of $\mathrm{N}$ dose was divided into two equal applications; one was added after 25 days from sowing and the second at the following irrigation. Other agricultural practices such as weed and insect control were performed according to the Ministry of Agriculture recommendation in North Nile Delta area.

The irrigation water applied was calculated to raise the soil water content of the upper $15 \mathrm{~cm}$ to field capacity in the first month, of the upper $30 \mathrm{~cm}$ in the second month and of the upper $45 \mathrm{~cm}$ in the rest period. Irrigation was stopped three weeks before harvesting.

Actual water consumptive use consists of the two components;

1-water applied (Wa) where water applied for irrigation was determined according to Phocaides (2001) as follow:-

$$
(\mathbf{W a})=\mathbf{f}(\mathbf{F c}-\mathbf{W P}) * \mathbf{B D} * \mathbf{D s}
$$

Where:

$\mathrm{Fc}=$ field capacity $(\%), \quad \mathrm{WP}=$ wilting point $(\%)$.

$\mathrm{f}=$ permissible depletion, $\mathrm{BD}=$ bulk density $\left(\mathrm{g} \mathrm{cm}^{-3}\right)$ Ds $=$ soil layer

2- rainfall $(\mathrm{R})$, where the total amount of the rainfall (R) was $41.29 \mathrm{~mm}\left(173.43 \mathrm{~m}^{3} \mathrm{fed}^{-1}\right)$ and $38.55 \mathrm{~mm}$ $\left(161.89 \mathrm{~m}^{3} \mathrm{fed}^{-1}\right)$ in the $1^{\text {st }}$ and $2^{\text {nd }}$ seasons, respectively. The number of irrigation, total amount of water applied for each irrigation and the rainfall (R) are shown in Table (1).

Table (1): The mean values of number of irrigation, total amount of water applied for each irrigation and the rainfall $(R)$ for both seasons.

\begin{tabular}{lccccccc}
\hline \multirow{2}{*}{ depletion } & \multirow{2}{*}{ N-levels } & \multicolumn{3}{c}{ Season 2013/2014 } & \multicolumn{3}{c}{$\begin{array}{c}\text { Season 2014/2015 } \\
\text { Total Wa }\end{array}$} \\
& & No. irr. & Total Wa & R & No. irr. & R \\
\hline \multirow{3}{*}{$45 \%$} & $\mathrm{~N}_{0}$ & 6 & 1105.11 & 173.43 & 6 & 1105.45 & 161.89 \\
& $\mathrm{~N}_{75 \%}$ & 7 & 1298.15 & 173.43 & 7 & 1293.16 & 161.89 \\
& $\mathrm{~N}_{100 \%}$ & 8 & 1570.96 & 173.43 & 8 & 1576.05 & 161.89 \\
& $\mathrm{~N}_{125 \%}$ & 9 & 1819.94 & 173.43 & 9 & 1817.21 & 161.89 \\
$60 \%$ & $\mathrm{~N}_{0}$ & 4 & 1053.84 & 173.43 & 4 & 1062.44 & 161.89 \\
& $\mathrm{~N}_{75 \%}$ & 5 & 1234.07 & 173.43 & 5 & 1248.20 & 161.89 \\
& $\mathrm{~N}_{100 \%}$ & 6 & 1445.32 & 173.43 & 6 & 1482.80 & 161.89 \\
$75 \%$ & $\mathrm{~N}_{125 \%}$ & 7 & 1618.41 & 173.43 & 7 & 1715.61 & 161.89 \\
& $\mathrm{~N}_{0}$ & 3 & 988.49 & 173.43 & 3 & 998.66 & 161.89 \\
& $\mathrm{~N}_{75 \%}$ & 4 & 1174.79 & 173.43 & 4 & 1168.40 & 161.89 \\
& $\mathrm{~N}_{100 \%}$ & 5 & 1398.73 & 173.43 & 5 & 1390.58 & 161.89 \\
& $\mathrm{~N}_{125 \%}$ & 6 & 1573.90 & 173.43 & 6 & 1666.93 & 161.89 \\
\hline
\end{tabular}

Soil samples (0-15, 15-30 and 30-45 cm depth) from each lysimeter were taken before planting and after harvesting in the two seasons, air-dried, gently crushed and sieved to pass a $2 \mathrm{~mm}$ sieve to determine 
some chemical and physical soil properties as shown in Table (2).

Method of analysis:

- Soil reaction (pH) according to Cottenie et al., (1982), Electrical conductivity (ECe), soluble cations and anions according to Page (1982). Organic matter (OM) content was determined using (Walkally Black - method) according to Hesse, (1971). Available N and $\mathrm{K}$ were determined according to Jackson (1967). Available $\mathrm{P}$ was determined by sodium bicarbonate method according to Olsen et al., (1954). The cation exchange capacity (CEC) was determined as described by Jackson (1967). Mechanical soil analysis and $\mathrm{CaCO}_{3} \%$ were determined according to the international pipette method (Piper, 1950). Field capacity (F.C.) and permanent wilting point (PWP) were determined by using pressure membrane method at 0.33 and 15 atm (Klute, 1986). Available water value is the difference between the field capacity and the permanent wilting point.

Table (2): The average values of some chemical, physical and soil moisture characteristics of the experimental soil before wheat planting.

\begin{tabular}{|c|c|c|c|}
\hline Seasons & & $1^{\text {st }}$ & $2^{\text {nd }}$ \\
\hline pH $1: 2.5$ & & 8.33 & 8.28 \\
\hline \multirow[t]{2}{*}{$\mathrm{EC}_{\mathrm{e}} \mathrm{dS} / \mathrm{m}$} & & 2.90 & 2.73 \\
\hline & $\mathrm{Na}^{+}$ & 18.99 & 17.83 \\
\hline Soluble cations & $\mathrm{Ca}^{++}$ & 4.06 & 3.86 \\
\hline \multirow[t]{3}{*}{$($ meq /L) } & $\mathrm{Mg}^{++}$ & 6.03 & 5.33 \\
\hline & $\mathrm{K}^{+}$ & 0.25 & 0.27 \\
\hline & $\mathrm{CO}_{3}^{--}$ & 0 & 0 \\
\hline Soluble anions & $\mathrm{HCO}_{3}^{-}$ & 3.33 & 3.17 \\
\hline \multirow[t]{3}{*}{$(\mathrm{meq} / \mathrm{L})$} & $\mathrm{Cl}^{-}$ & 14.04 & 13.46 \\
\hline & $\mathrm{SO}_{4}^{--}$ & 11.95 & 10.67 \\
\hline & $\mathrm{N}$ & 17.17 & 19.41 \\
\hline \multirow[t]{3}{*}{ Available (mg/kg) } & $\mathrm{P}$ & 9.18 & 12.47 \\
\hline & $\mathrm{K}$ & 303.43 & 290.42 \\
\hline & Sand & 18.61 & 20.11 \\
\hline \multirow{2}{*}{ Soil mechanical analysis $(\%)$} & Silt & 31.68 & 31.99 \\
\hline & Clay & 49.71 & 47.9 \\
\hline Texture grade & & clay & clay \\
\hline $\mathrm{OM} \%$ & & 1.15 & 1.10 \\
\hline Total $\mathrm{CaCO}_{3}(\%)$ & & 2.32 & 2.28 \\
\hline CEC meg/100 g soil & & 38.58 & 39.50 \\
\hline Field capacity (\%) & & 39.26 & 39.38 \\
\hline Wilting point (\%) & & 21.34 & 21.40 \\
\hline Available water $(\%)$ & & 17.92 & 17.98 \\
\hline Bulk density $\left(\mathrm{g} \mathrm{cm}^{-3}\right)$ & & 1.17 & 1.18 \\
\hline
\end{tabular}

Dry materials of plant organs (oven dry basis) were wet digested with an $\mathrm{H}_{2} \mathrm{SO}_{4}-\mathrm{H}_{2} \mathrm{O}_{2}$ mixture as described by Wolf (1982) and analyzed for the following:

- Nitrogen content was determined by micro-Kjeldahl method (Jackson, 1967).

- Phosphorus was determined by using hydroquinine method (Snell and Snell, 1967).

- Potassium content was determined by using a flame photometer (Jackson 1967).

The following parameters were calculated:

- Apparent N Recovery (ANR): by the equation described by Echeverria and Videla (1998), i.e., ANR $(\%)=[\mathrm{N}$ uptake (fertilized plot) $-\mathrm{N}$ uptake (zero plot) / N fertilizer rate] X 100.

- Nitrogen Agronomic Efficiency (NAE) according to Craswell and Godwin (1984): [grain yield (fertilized plot) - grain yield (zero plot)] / $\mathrm{N}$ rate.

- Water use efficiency (WUE): was calculated by dividing the total weight of grain yield $\left(\mathrm{kg} \mathrm{fed}^{-1}\right)$ by the amount of seasonal water consumptive use $\left(\mathrm{m}^{3}\right.$ fed $^{-1}$ ) Talha et al., (1980).

\section{WUE $\left(\mathrm{Kg} \mathrm{m}^{3}\right)=\quad$ Grain yield $\left(\mathrm{kg} \mathrm{fed}^{-1}\right)$ \\ WCU $\left(\mathrm{m}^{3}\right.$ fed $\left.^{-1}\right)$}

Where: $\mathrm{WCU}=$ actual water consumptive use

All measurements data during the two seasons in this study were statistically analyzed according to the methods described by Snedecor and Cochran (1980). The differences among the means of different treatments were tested using the Least Significant Differences (LSD) at probability 5\%. Statistical analysis was done using the CoStat package program, version 6.311 (Cohort software, USA).

\section{RESULTS AND DISCUSSION}

\section{1- Grain yield:}

Data presented in Table (3) show the effect of soil moisture depletion, nitrogen fertilization levels and their interaction on grain yield.

Data point out that soil moisture depletion treatment high significantly decreased the grain yield in both seasons. Means of wheat grain yield were 2157.31, 2006.46, $1807.58 \mathrm{~kg} \mathrm{fed}^{-1}$ and 2219.35, 1951.60, $1825.25 \mathrm{~kg} \mathrm{fed}^{-1}$ under irrigation after depletion $45 \%$, 
$60 \%$ and $75 \%$ from available water in the first and second season, respectively. Hence irrigation after depletion $45 \%$ from available water increase grain yield by $(19.35 \%$ and $21.59 \%)$ than that irrigation after depletion $75 \%$ from available water in the first and second season, respectively. This is to be expected since drought stress might reduce translocation of assimilates from leaves, this response in addition to reduce photosynthesis in the leaves itself contribute to lower grain yield. Conversely, water deficit at any growth stage reduce grain yield. These results are in the same line with Beshara (2012) and Hammad - Salwa and Ali (2014).

Adding nitrogen fertilizer up to $125 \%$ from the recommended dose $\left(93.75 \mathrm{~kg} \mathrm{~N}^{-1} \mathrm{~d}^{-1}\right)$ high significantly increased grain yield $\left(\mathrm{kg} \mathrm{fed}^{-1}\right)$. Nitrogen application at rate of $125 \%$ increases grain yield by $1647.42,585.95$ and $282.43 \mathrm{~kg} \mathrm{fed}^{-1}$ in the first season and by 1629.6 , 412.07 and $190.87 \mathrm{~kg} \mathrm{fed}^{-1}$ in the second season than that of control, $75 \%$ and $100 \%$ of $\mathrm{N}$ recommended dose, respectively. It can be concluded that the increasing amount of nitrogen fertilizer, consequently get higher grain yield. These results are in conformity with ElGizawy (2005); Mosaad et al., (2013) and Gazia and Abd EL Aziz (2013).

High significantly effect was found by the interaction between soil moisture depletion and nitrogen fertilizer levels on grain yield in both seasons. The highest values of grain yield are realized by applying the treatment of irrigation after depletion $45 \%$ from available water $+125 \%$ of $\mathrm{N}$ recommended dose for both seasons. Grain yield reduced in each season by increasing soil moisture depletion at all nitrogen rates in both seasons. Data of Table 3 state also that the obtained grain yield from applying the recommended $\mathrm{N}$ dose $\left(75 \mathrm{~kg} \mathrm{~N} \mathrm{fed}^{-1}\right)$ and irrigation after depletion $45 \%$ from available water $\left(2542.40 \mathrm{~kg} \mathrm{fed}^{-1}\right.$ in the $1^{\text {st }}$ season) can be realized by increasing the dose of $\mathrm{N}$ to $125 \%$ from the recommended $\left(93.75 \mathrm{~kg} \mathrm{~N} \mathrm{fed}^{-1}\right)$ and delay the irrigation to be done after depletion $60 \%$ from available water $\left(2633.40 \mathrm{~kg}_{\text {grains }} \mathrm{fed}^{-1}\right.$ in the $1^{\text {st }}$ season)

Table (3): Effect of soil moisture depletion, $\mathbf{N}$ fertilization levels and their interactions on grain yield (kg fed $\left.{ }^{-1}\right)$

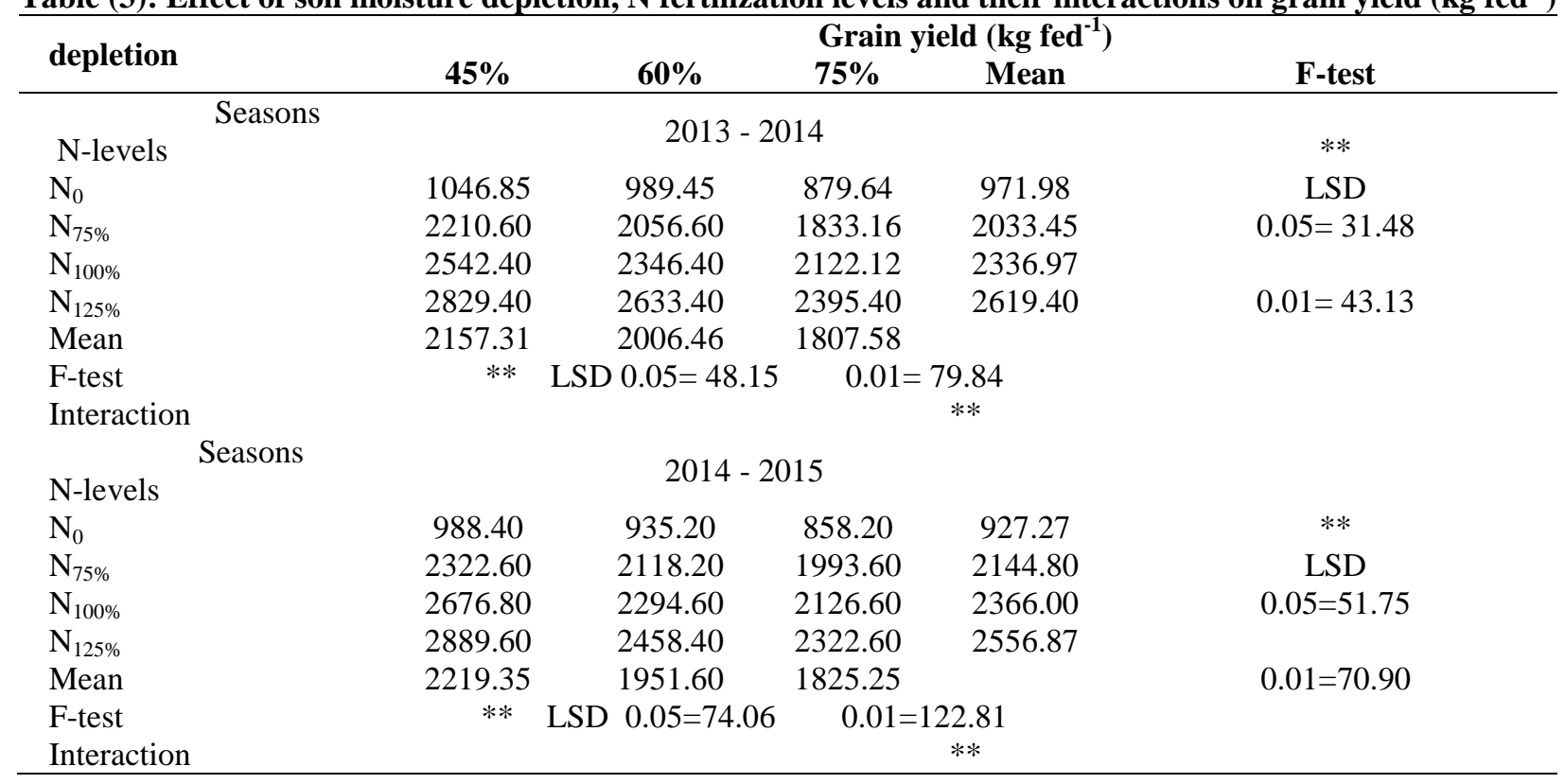

\section{2-Straw yield:}

Data presented in Table (4) show the effect of soil moisture depletion, nitrogen fertilization levels and their interaction on wheat straw yield.

Data indicate that soil moisture depletion treatments significantly decreased wheat straw yield in both seasons. The highest mean values of wheat straw yield are 3355.19 and $3297 \mathrm{~kg} \mathrm{fed}^{-1}$ under irrigation after depletion $45 \%$ from available water in the first and second season, respectively. No significant differences in the straw yield were found as affected by irrigation after depletion $45 \%$ and $60 \%$ from available water in first season. Also the lowest mean values are 3080.98 and $3127.25 \mathrm{~kg} \mathrm{fed}^{-1}$ under irrigation after depletion $75 \%$ from available water in the first and second season, respectively, without significant difference as compared with irrigation after depletion $60 \%$ from available water in the second season. The increase in growth and productivity of wheat due to increasing irrigation water may be due to provide moisture for wheat plants continuously which allows better growth, thereby enhancement yield components resulting in increments in plant height and straw yield. Similar results are given by previous researchers Beshara, (2012) and HammadSalwa and Ali (2014)

Different $\mathrm{N}$ rates $75 \%, 100 \%$ and $125 \%$ of $\mathrm{N}$ recommended dose high significantly increased straw yield by $22.46 \%$ at $\mathrm{N}_{75 \%}, 31.61 \%$ at $\mathrm{N}_{100 \%}$ and $43.39 \%$ at $\mathrm{N}_{125 \%}$ in first season and by $18.71 \%$ at $\mathrm{N}_{75 \%}, 24.79 \%$ at $\mathrm{N}_{100 \%}$ and $26.26 \%$ at $\mathrm{N}_{125 \%}$ in second season, as compared to control. Insignificant differences between $100 \%$ and $125 \%$ of $\mathrm{N}$ recommended dose in second season were found. It can be concluded that the increasing amount of nitrogen fertilizer, the straw yield 
gradually improve because encourage vegetative growth and thus on plant height and branches, so on the straw yield. These results are in harmony with those obtained by Mosaad et al., (2013).
No interaction effects were found between soil moisture depletion and nitrogen fertilization levels on wheat straw yield in both seasons.

Table (4): Effect of soil moisture depletion, fertilization levels and their interactions on straw yield $\left(\mathrm{kg} \mathrm{fed}^{-1}\right)$ :

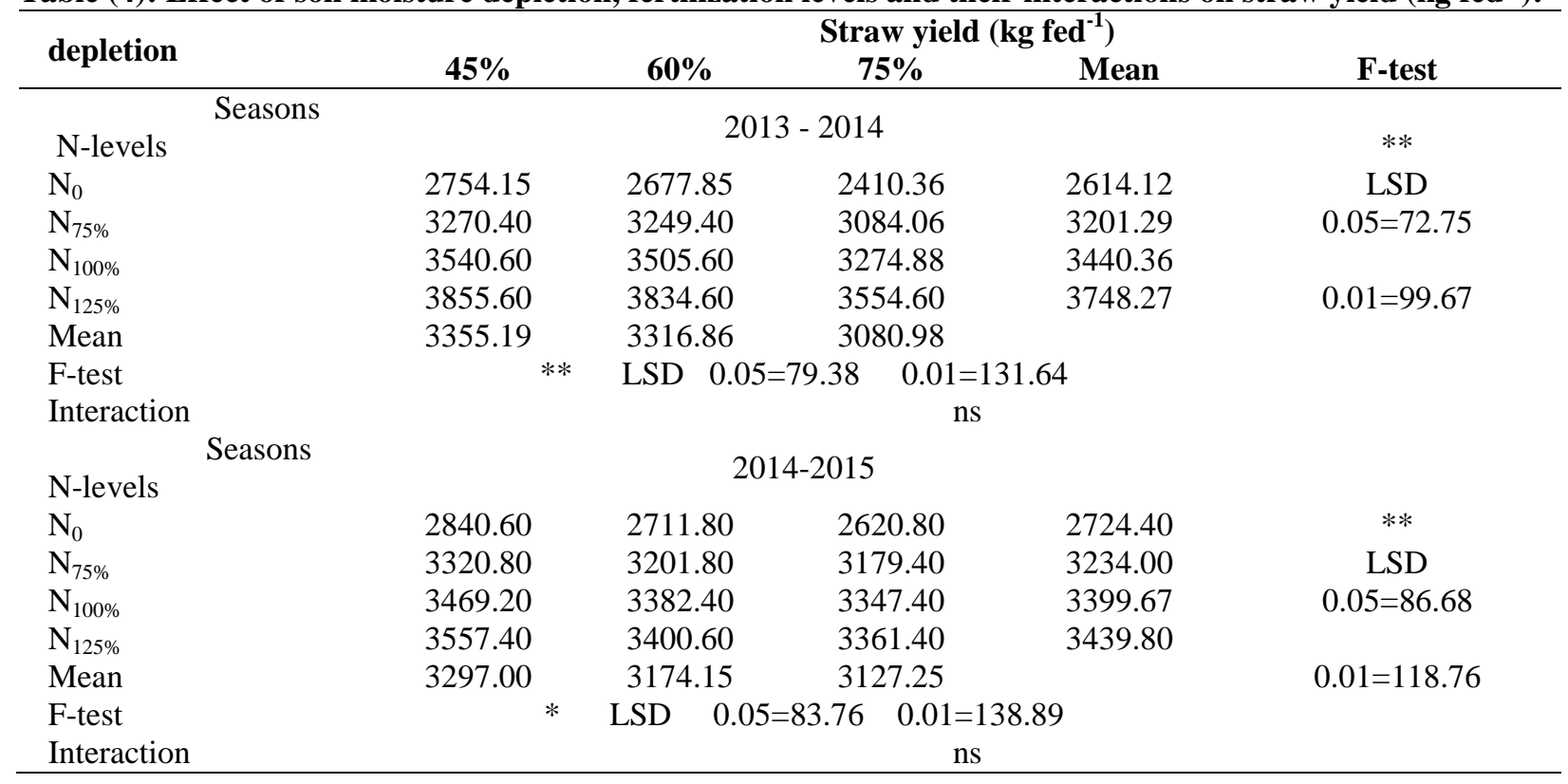

\section{3-Total Nitrogen uptake by wheat:}

Data presented in Table (5) show the effect of soil moisture depletion, nitrogen fertilization levels and their interactions on total nitrogen uptake by wheat (grain + straw uptake).

Total nitrogen uptakes are high significantly affected by soil moisture depletion treatments in the two growing seasons. Mean values are 54.32, 49.34, 43.38 $\mathrm{kg} \mathrm{N} \mathrm{fed}^{-1}$ and 62.22, 53.86, 46.97 kg N fed ${ }^{-1}$ under irrigation after depletion $45 \%, 60 \%$ and $75 \%$ from available water in first and second seasons, respectively.
Irrigation after depletion $45 \%$ from available water increased the total $\mathrm{N}$ uptake by $4.98,10.94 \mathrm{~kg} \mathrm{~N}$ fed $^{-1}$ and by $8.36,15.25 \mathrm{~kg} \mathrm{~N}_{\text {fed }}{ }^{-1}$ in the $1^{\text {st }}$ and $2^{\text {nd }}$ season as compared with irrigation after depletion $60 \%$ and $75 \%$ from available water, respectively. These results may be attributed to the increase in soil moisture content in the plant root zone which led to an increase in available nutrient and increase $\mathrm{N}$ uptake by wheat plant. These results were recorded by Beshara, (2012) and Hammad Salwa and Ali (2014).

Table (5) Effect of soil moisture depletion and nitrogen fertilization levels on total $\mathrm{N}$ uptake $\left(\mathrm{kg} \mathrm{N} \mathrm{fed}^{-1}\right)$ :

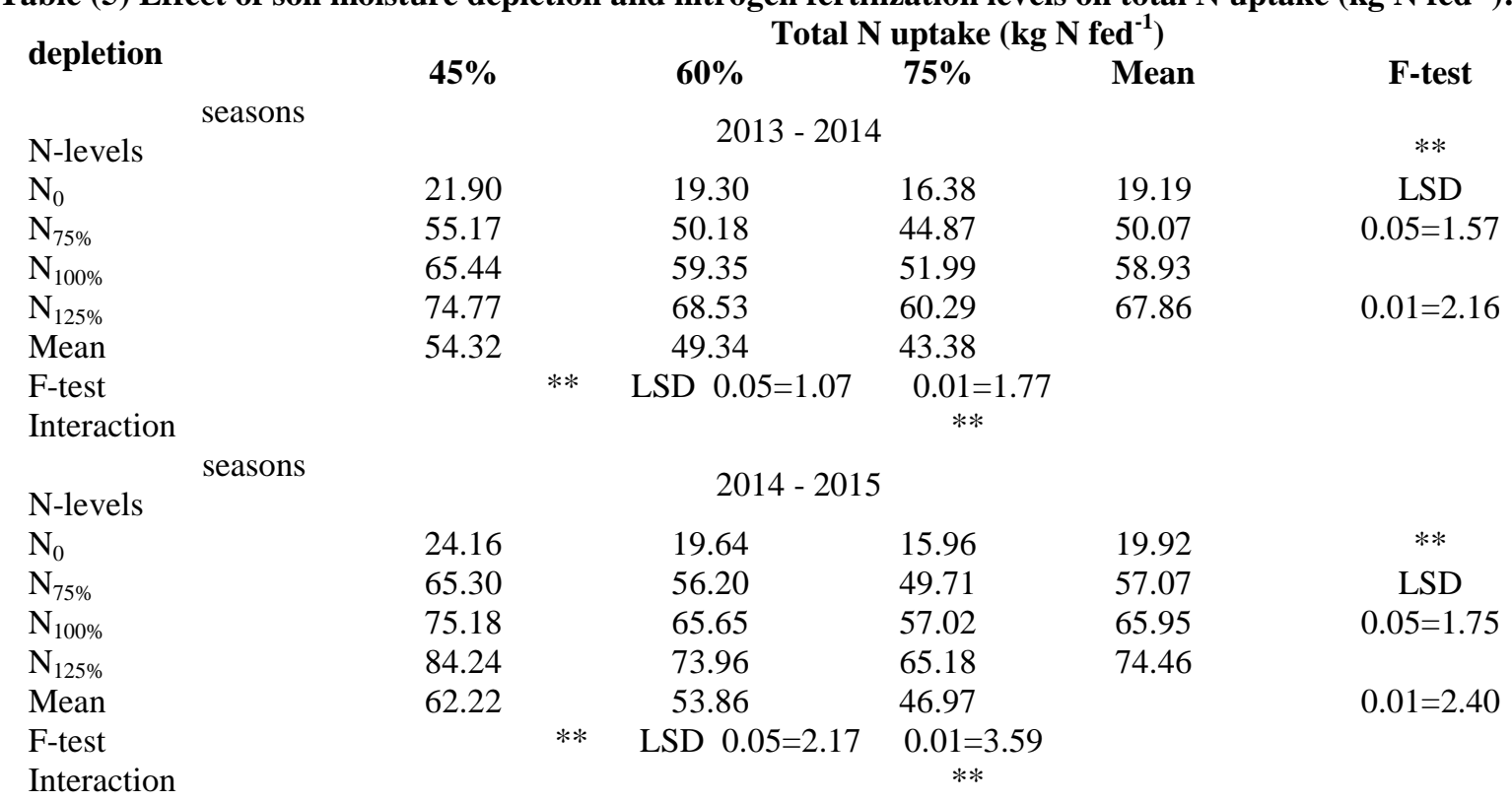


Data in Table 5 also reveal that nitrogen fertilization levels in both seasons high significantly affected the total $\mathrm{N}$ uptake by wheat plant. The highest values of total nitrogen uptake are 67.86 and $74.46 \mathrm{~kg} \mathrm{~N}$ $\mathrm{fed}^{-1}$ under $125 \%$ of $\mathrm{N}$ recommended dose while the lowest values are 19.19 and $19.92 \mathrm{~kg} \mathrm{~N}$ fed $^{-1}$ under control (zero $\mathrm{N}$ addition. Mean values of $75 \%$ and $100 \%$ of $\mathrm{N}$ recommended dose are $50.07,58.93 \mathrm{~kg} \mathrm{~N}^{-1} \mathrm{fed}^{-1}$ and $57.07,65.95 \mathrm{~kg} \mathrm{~N} \mathrm{fed}^{-1}$ in $1^{\text {st }}$ and $2^{\text {nd }}$ seasons, respectively. This may be due to the available nitrogen in the soil are less under the low levels and are enough in the high level, also increasing nitrogen fertilizer levels led to increase nitrogen uptake by plants. These results are in line with Rahman et al., (2011).

There are high significant differences in total nitrogen uptake in the both seasons due to the interaction between soil moisture depletion and nitrogen fertilization levels. It could be noticed that irrigation after depletion $45 \%$ from available water with fertilization at $125 \%$ of recommended dose gave the highest values of nitrogen total uptake by wheat. On the contrary, the lowest total nitrogen uptakes by wheat are obtained from irrigation at $75 \%$ available water without nitrogen fertilization in the two growing seasons.

4- Nitrogen agronomic efficiency (NAE):

Data presented in Table (6) show the effect of soil moisture depletion, nitrogen fertilization levels and their interaction on nitrogen agronomic efficiency by wheat grains ( $\mathrm{kg}$ grain $\left.\mathrm{kg} \mathrm{N}^{-1}\right)$.

Data reveal that soil moisture depletion significantly affected NAE, where irrigation after depletion $75 \%$ from available water decreased NAE by $16.70 \%$ and $9.01 \%$ than that of irrigation after depletion $45 \%$ and $60 \%$ from available water, in first season, respectively. While in second season these decreases were $20.74 \%$ and $4.87 \%$ than that of irrigation after depletion $45 \%$ and $60 \%$ from available water, respectively. Insignificant differences were found between mean values of NAE due to irrigation after depletion $60 \%$ and $75 \%$ from available water in second season. The data reveal that the unit of nitrogen $(\mathrm{kg})$ produces more grains yield when plant was irrigated after depletion of $45 \%$ from available water than $60 \%$ and $75 \%$.

Table (6) Effect of soil moisture depletion and nitrogen fertilization levels on nitrogen agronomic efficiency (NAE) Kg grains Kg $\mathrm{N}^{-1}$ for wheat:

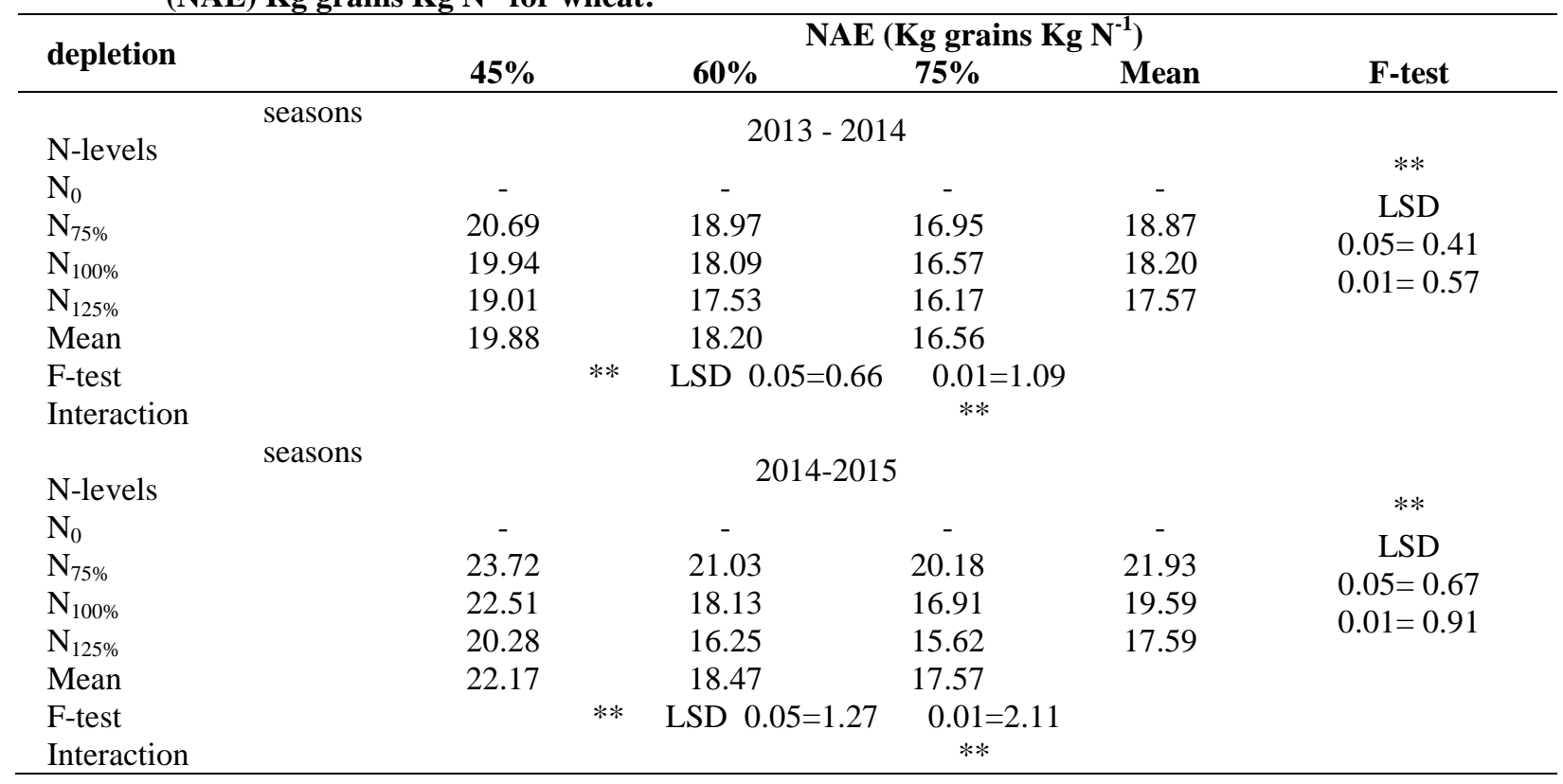

Nitrogen fertilization levels greatly affect NAE, where significant decreases were found with increasing $\mathrm{N}$ fertilization level. The highest mean values 18.87 and $21.93 \mathrm{~kg}_{\text {grain }} \mathrm{kg} \mathrm{N}^{-1}$ were achieved under application of $75 \%$ of $\mathrm{N}$ recommended dose and the lowest mean values 17.57 and $17.59 \mathrm{~kg}$ grain $\mathrm{kg} \mathrm{N}^{-1}$ were recorded under application of $125 \%$ of $\mathrm{N}$ recommended dose. While mean values were 18.20 and $19.59 \mathrm{~kg}_{\text {grain }} \mathrm{kg} \mathrm{N}^{-}$ ${ }^{1}$ under application of $100 \%$ of $\mathrm{N}$ recommended dose in the $1^{\text {st }}$ and $2^{\text {nd }}$ seasons, respectively. These results are in agreement with Rahman et al., (2011) and Noureldin et al., (2013).

Concerning the interaction effect data reveal that high significant interactions between soil moisture depletion and $\mathrm{N}$ fertilization levels on NAE were obtained. The highest values of NAE 20.69 and 23.72 $\mathrm{kg}$ grain $\mathrm{kg} \mathrm{N}^{-1}$ were recorded under irrigation after depletion $45 \%$ from available water $+75 \%$ of $\mathrm{N}$ recommended dose. The lowest values (16.17 and 15.62 $\mathrm{kg}$ grain $\mathrm{kg} \mathrm{N}^{-1}$ ) were achieved under irrigation after depletion $75 \%$ from available water $+125 \%$ of $\mathrm{N}$ recommended dose. It can be said that NAE increases by decreasing soil moisture depletion and $\mathrm{N}$-levels in both seasons.

\section{5- Apparent $\mathrm{N}$ recovery (ANR) by wheat (\%):}

Data presented in Table (7) show the effect of soil moisture depletion, nitrogen fertilization levels and their interaction on apparent nitrogen recovery (ANR) by wheat $(\%)$.

Data point out that soil moisture depletion treatment high significantly affected ANR in both seasons. The mean values of apparent nitrogen recovery 
by wheat are $57.87,53.61,48.13 \%$ and $68.41,61.43$ and $55.74 \%$ under irrigation after depletion $45 \%, 60 \%$ and $75 \%$ from available water in the first and second season, respectively. Hence irrigation after depletion $75 \%$ from available water decreased ANR by (17.62 \% and $10.55 \%)$ and $(19.46 \%$ and $10.06 \%)$ than that irrigation after depletion $45 \%$ and $60 \%$ from available water in the first and second season, respectively.

Raising nitrogen fertilizer levels negatively and high significantly affected ANR (\%). $125 \%$ of $\mathrm{N}$ recommended dose decreased ANR by (5.38 and 1.98 $\%)$ in the first season and (11.92 and $5.21 \%)$ in the second season than that of $75 \%$ and $100 \%$ of $\mathrm{N}$ recommended dose, respectively. Similar results were given by previous researchers Faizy et al., (2010) and Haile et al., (2012).

Apparent nitrogen recovery values by wheat were high significant affected by the interaction between soil moisture depletion and nitrogen fertilizer levels in both seasons. The highest values of apparent nitrogen recovery by wheat were realized by applying the treatment of irrigation after depletion $45 \%$ from available water $+75 \%$ of $\mathrm{N}$ recommended dose for both seasons. Apparent nitrogen recovery by wheat reduced in each season by increasing soil moisture depletion at all nitrogen rates in both seasons.

Table (7) Effect of soil moisture depletion and $\mathbf{N}$ fertilization levels on apparent $\mathbf{N}$ recovery (ANE) \% by wheat (grains + straw):

\begin{tabular}{|c|c|c|c|c|c|c|c|}
\hline \multirow{2}{*}{ depletion } & & \multicolumn{6}{|c|}{ Apparent $\mathrm{N}$ recovery $(\%)$} \\
\hline & & \multicolumn{2}{|l|}{$45 \%$} & $60 \%$ & $75 \%$ & Mean & F-test \\
\hline & Seasons & \multicolumn{5}{|c|}{$2013-2014$} & \multirow{4}{*}{$\begin{array}{c}* * \\
\text { LSD } \\
0.05=2.08\end{array}$} \\
\hline N-levels & & & & & & & \\
\hline $\mathrm{N}_{0}$ & & - & & - & - & - & \\
\hline $\mathrm{N}_{75 \%}$ & & 59.14 & & 54.91 & 50.41 & 54.82 & \\
\hline $\mathrm{N}_{100 \%}$ & & 58.06 & & 53.40 & 47.30 & 52.92 & \multirow{3}{*}{$0.01=2.85$} \\
\hline $\mathrm{N}_{125 \%}$ & & 56.40 & & 52.51 & 46.69 & 51.87 & \\
\hline Mean & & 57.87 & & 53.61 & 48.13 & & \\
\hline F-test & & \multirow{2}{*}{\multicolumn{2}{|c|}{$* *$}} & LSD $0.05=2.29$ & \multirow{2}{*}{\multicolumn{2}{|c|}{$\begin{array}{l}0.01=3.79 \\
* *\end{array}$}} & \multirow{8}{*}{$0.01=3.43$} \\
\hline Interaction & & & & & & & \\
\hline & Seasons & \multicolumn{5}{|c|}{ 2014-2015 } & \\
\hline $\begin{array}{l}\mathrm{N} \text {-levels } \\
\mathrm{N}_{0}\end{array}$ & & - & & - & - & - & \\
\hline $\mathrm{N}_{75 \%}$ & & 73.13 & & 65.01 & 60.00 & 66.04 & \\
\hline $\mathrm{N}_{100 \%}$ & & 68.02 & & 61.35 & 54.74 & 61.37 & \\
\hline $\mathrm{N}_{125 \%}$ & & 64.08 & & 57.94 & 52.49 & 58.17 & \\
\hline Mean & & 68.41 & & 61.43 & 55.74 & & \\
\hline F-test & & \multirow{2}{*}{\multicolumn{2}{|c|}{$* *$}} & \multirow{2}{*}{\multicolumn{3}{|c|}{$\begin{array}{l}0.01=5.40 \\
* *\end{array}$}} & \\
\hline Interaction & & & & & & & \\
\hline
\end{tabular}

\section{6- Actual water consumptive use:}

Data presented in Table (8) show the effect of soil moisture depletion, nitrogen fertilization levels and their interaction on actual water consumptive use of wheat yield.

Table (8) Effect of soil moisture depletion and $\mathrm{N}$ fertilization levels on actual water consumptive use $\left(\mathrm{m}^{3} \mathrm{fed}^{-1}\right)$

\begin{tabular}{|c|c|c|c|c|}
\hline \multirow{2}{*}{ depletion } & \multicolumn{4}{|c|}{ Actual water consumptive use $\left(\mathrm{m}^{3}\right.$ fed $\left.^{-1}\right)$} \\
\hline & $45 \%$ & $60 \%$ & $75 \%$ & Mean \\
\hline N_levels & \multicolumn{4}{|c|}{$2013-2014$} \\
\hline $\mathrm{N}_{0}$ & 1278.54 & 1227.27 & 1161.92 & 1222.58 \\
\hline $\mathrm{N}_{75 \%}$ & 1471.58 & 1407.5 & 1348.22 & 1409.10 \\
\hline $\mathrm{N}_{100 \%}$ & 1744.39 & 1618.75 & 1572.16 & 1645.10 \\
\hline $\mathrm{N}_{125 \%}$ & 1993.37 & 1799.33 & 1747.33 & 1846.68 \\
\hline Mean & 1621.97 & 1513.21 & 1457.41 & \\
\hline \multicolumn{2}{|c|}{ Seasons } & \multicolumn{2}{|c|}{ 2014-2015 } & \\
\hline $\mathrm{N}_{0}$ & 1267.34 & 1224.33 & 1160.55 & 1217.41 \\
\hline $\mathrm{N}_{75 \%}$ & 1455.05 & 1410.09 & 1330.29 & 1398.48 \\
\hline $\mathrm{N}_{100 \%}$ & 1737.94 & 1644.69 & 1552.47 & 1645.03 \\
\hline $\mathrm{N}_{125 \%}$ & 1979.10 & 1877.50 & 1828.82 & 1895.14 \\
\hline Mean & 1609.86 & 1539.15 & 1468.03 & \\
\hline
\end{tabular}

Data state that the decreasing $\%$ in actual water consumptive use values under irrigation after depletion $60 \%$ and $75 \%$ of available water compared to irrigation after depletion $45 \%$ of available water by (6.71 and $10.15 \%)$ and $(4.39$ and $8.81 \%)$ in $1^{\text {st }}$ and $2^{\text {nd }}$ seasons respectively. These results are attributed to more 
available soil moisture, under irrigation after depletion $45 \%$ of available water, which enhanced both transpiration from plants leaves and evaporation from the soil surface.

The addition of $125 \%$ from recommended dose cause increasing in actual water consumptive use of wheat crop. Average values of actual water consumptive use are $\left(1846.68\right.$ and $\left.1895.14 \mathrm{~m}^{3} \mathrm{fed}^{-1}\right), \quad(1645.10$ and $\left.1645.03 \mathrm{~m}^{3} \mathrm{fed}^{-1}\right)$ and $\left(1409.10\right.$ and $\left.1398.48 \mathrm{~m}^{3} \mathrm{fed}^{-1}\right)$ for $125 \%, 100 \%$ and $75 \%$ from recommended $\mathrm{N}$ dose in both seasons, respectively, these results could be caused due to increase the wheat yield which led to increases in water consumptive use.

Concerning to the interaction effect between soil moisture depletion and nitrogen fertilizer levels effect on actual water consumptive use in both seasons, data reveal that the highest values were obtained with irrigation at depletion of $45 \%$ of available water $+125 \%$ of $\mathrm{N}$ recommended dose comparing with other soil moistures and nitrogen rates.

\section{7- Water use efficiency:}

Data presented in Table (9) show the effect of soil moisture depletion, nitrogen fertilization levels and their interaction on water use efficiency.

Water use efficiency for the grain yield was affected by soil moisture depletion levels and was highly significant. The mean values of WUE due to the irrigation after depletion $45 \%$ of available water are significantly different from that irrigation after depletion $60 \%$ and $75 \%$ of available water. The highest WUE (1.31 and $1.34 \mathrm{~kg}$ grain $\mathrm{m}^{-3}$ water consumed) and the lowest (1.21 and $1.23 \mathrm{~kg}_{\text {grain }} \mathrm{m}^{-3}$ water consumed) for both seasons were observed at 45 and $75 \%$ SMD levels, respectively. These indicated that $75 \%$ of soil moisture depletion reduce WUE for grain yield. The results agree with the result of Mahamed et al., (2011) and Beshara (2012).

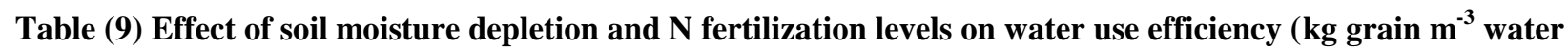
consumed)

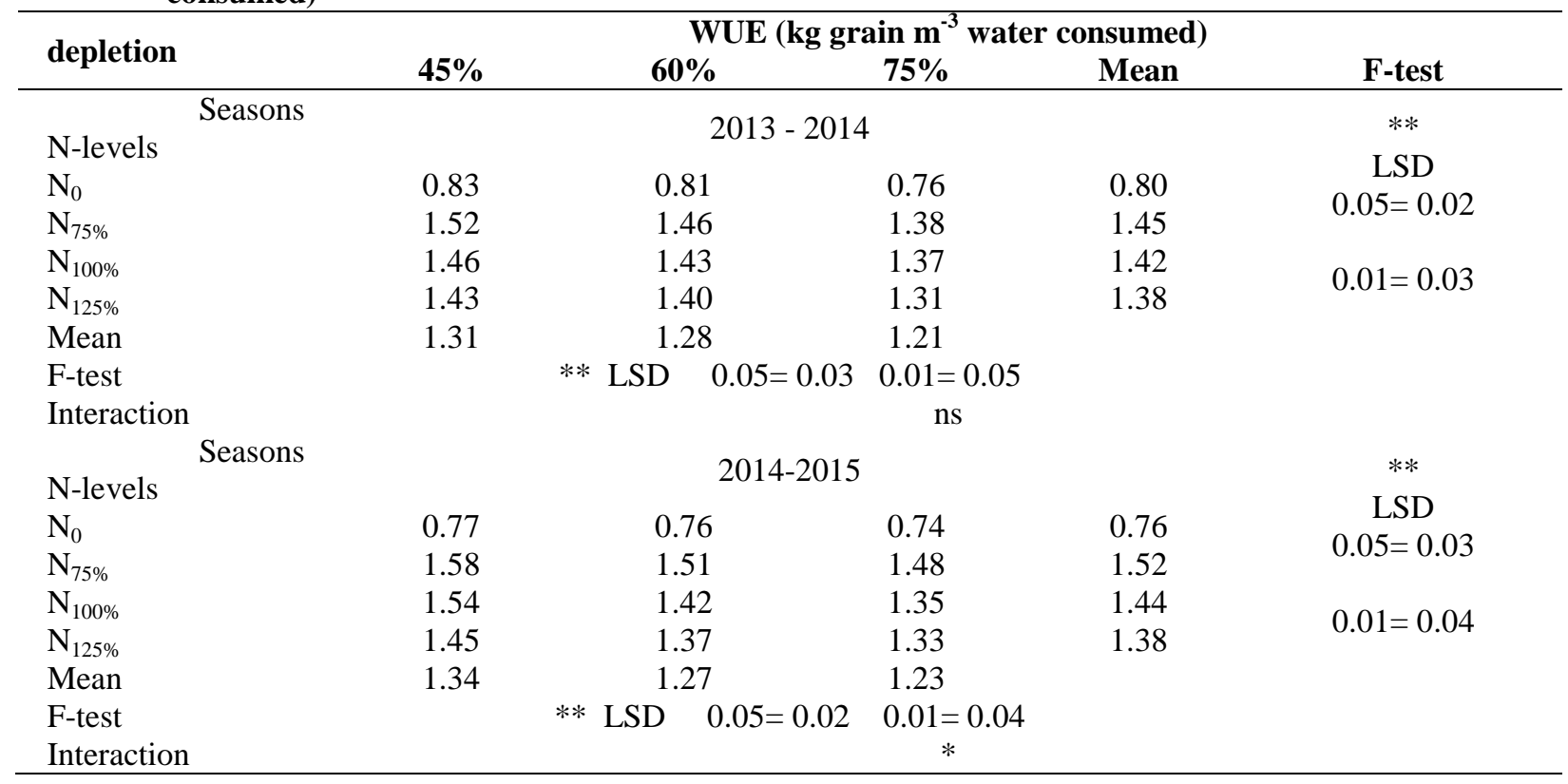

The effect of nitrogen at various levels on WUE were high statistically different in all cases. Maximum WUE of (1.45 and $1.52 \mathrm{~kg}_{\text {grain }} \mathrm{m}^{-3}$ water consumed) were obtained when $\mathrm{N}$ apply at level of $75 \%$ from $\mathrm{N}$ recommended dose. The lowest WUE $(0.80$ and $0.76 \mathrm{~kg}$ grain $\mathrm{m}^{-3}$ water consumed) were achieved without nitrogen application for both seasons, respectively.

Likewise, the interactions between soil moisture depletion and nitrogen fertilizer levels on WUE were insignificant in first season and significant in second seasons. The highest value of WUE was obtained from treatments of irrigation after depletion $45 \%$ of available water and $75 \%$ from $\mathrm{N}$ recommended dose while the lowest value of WUE was revealed from the irrigation after depletion $75 \%$ of available water without addition of nitrogen fertilizer in both growing seasons.
These results could be attributed to the highly significant differences between the wheat grain yield values as well as differences water consumed use (Table 3 and 8).

\section{CONCLUSION}

It can be concluded that under natural conditions (water availability) wheat can be irrigated after depletion $45 \%$ from available water with fertilization at $125 \%$ of recommended dose which gave the highest mean values of grain production of wheat, On the other hand, under drought conditions (reducing water resources), other soil moisture treatments with different nitrogen levels can be used with expected decreasing in wheat productivity. 


\section{REFERENCES}

Beshara, A. T. (2012). Effect of Soil Moisture Depletion and Nitrogen Fertilizer Application Date on Wheat Yield, Water and Fertilizer Use Efficiencies in North Aferica. Ph. D. Thesis, Natural Resources, I.A.R.S., Cairo Univ., Egypt.

Cottenie, A.: Verloo, M.; Velghe, G and Kiekens, L. (1982). Biological and analytical aspects of soil pollution. Lab. Of Analytical Agro. State Univ. Gent-Belgium.

Craswell, E. T. and D. C. Godwin, (1984). The efficiency of nitrogen fertilizers applied to cereals in different climates. Adv. In Plant Nutrition, New York, 1: 1-55.

Echeverria, H. E. and C. C. Videla, (1998). Eficiencia fisiologica y de utilizacion de nitrogeno en trigo en la region pampeana Argentina. Ciencia del suelo 16: $83-87$.

El-Gizawy, N. Kh. B. (2005). Yield and nitrogen use efficiency as influenced by rates and sources of nitrogen fertilizers of some wheat varieties. Conference of Agronomy, Agron. Dept., Fac. Agric., Assiut Univ., 9:15-16.

Faizy, S. E. D. A.; M. M. Rizk; M. M. Ragab and M. M. A. Amer, (2010). Response of wheat yield and apparent nitrogen recovery of fertilizer to mineral nitrogen and biofertilizer application in salt affected soils. J. Agric. Res. Kafr El-Sheikh Univ., 36 (1).

Gazia, E. A. E. and M. A. Abd EL-Aziz, (2013). Maximizing wheat yield under N, K and B fertilization . J.Soil Sci. and Agric. Eng., Mansoura Univ., 4 (10): 1073 - 1084.

Haile, D.; D. Nigussie and A. Ayana, (2012). Nitrogen use efficiency of bread wheat: Effects of nitrogen rate and time of application. J. Soil Sci. and Plant Nutr. 12 (3): 389-409.

Hammad - Salwa. A. R. and O. A. M. Ali (2014). Physiological and biochemical studies on drought tolerance of wheat plants by application of amino acids and yeast extract. Ann. Agric. Sci., 59, (1): 133-145.

Hesse, P. R. (1971). A Text book of Soil Chemical Analysis. John Murray Ltd, London, pp. 520.

Jackson, M. L. (1967). "Soil Chemical Analysis". Prentice-Hall of India, New Delhi.

Klute , A. (1986). Methods of soil analysis (part 1). Amer. soc. Of Agron., Inc. Madison, Wisconsin, USA. $3^{\text {rd }}$ edition.
Mahamed, M. B.; E. Sarobol; T. Hordofa; S. Kaewrueng and J. Verawudh, (2011). Effects of Soil Moisture Depletion at Different Growth Stages on Yield and Water Use Efficiency of Bread Wheat Grown in Semi-Arid Conditions in Ethiopia. Kasetsart J. (Nat. Sci.) 45: 201 - 208.

Mosaad, I. S. M.; E. E. E. Khafagy and R. A. ElDissoky, (2013). Effect of mineral, bio and organic nitrogen fertilization on wheat yield and nitrogen utilization efficiency and uptake at northern delta of Egypt. J.Soil Sci. and Agric. Eng., Mansoura Univ., 4 (10): 1101 - 1116.

Noureldin Nemat, A.; H. S. Saudy; F. Ashmawy and H. M. Saed, (2013). Grain yield response index of bread wheat cultivars as influenced by nitrogen levels. Annals of Agricultural Science 58(2), 147-152.

Olsen, S. R.; C.V. Cale; F. S. Watenable and L. A. Dean, (1954). Estimation of available phosphorus in soil by extraction with sodium bicarbonate U.S. Dept., Agric. Circ., 939.

Page A. L. (ed.) (1982). Methods of Soil Analysis, part 2: Chemical and Microbiological properties, $\left(2^{\text {nd }}\right.$ ed.) American Society at Agronomy, Inc. Soil. Sci Soc. Of Am. Inc., Madison. Wisconsin, U S A.

Phocaides , A. (2001). Handbook on pressurized irrigation techniques .Food and Agriculture Organization of the United Nations, Rome.

Piper, C.S. (1950). Soil and Plant Analysis. Inter science Publication. New York.

Rahman, M. A.; M. A. Z. Sarker; M. F. Amin; A. H. S. Jahan and M. M. Akhter, (2011). Yield response and nitrogen use efficiency of wheat under different doses and split application of nitrogen fertilizer. Bangladesh J. Agril. Res. 36(2): 231-240.

Snedecor, G. W. and W. G. Cochran, (1980). Statistical Methods, seventh ed. The Iowa State Univ. Press, Ames. Iowa, USA, pp. 1-507.

Snell, F. D. and C. T. Snell, (1967). Colorimetric Methods of Analysis. D. Van. Nostranad company Inc.: $551-552$.

Talha, M.; M. A. Aziz, and E. M. El-Toni, (1980). The combined effect of irrigation intervals and cycocel treatments on Pelargonium graveolens L. II- Evapotranspiration and water economy. Egypt. J. Soil Sci., 20(2): 121

USDA, (2013). USDA Gain: Egypt grain and feed annual 2013: Forex availability impacts grain imports. USDA Foreign Agricultural Service

Wolf, (1982). A comprehensive system of leaf analysis and it is use for diagnosing crop nutrient status. Communic Soil Sci. and plant Analysis.13: 10351059. 
El-Agrodi, M.W.M. et al.

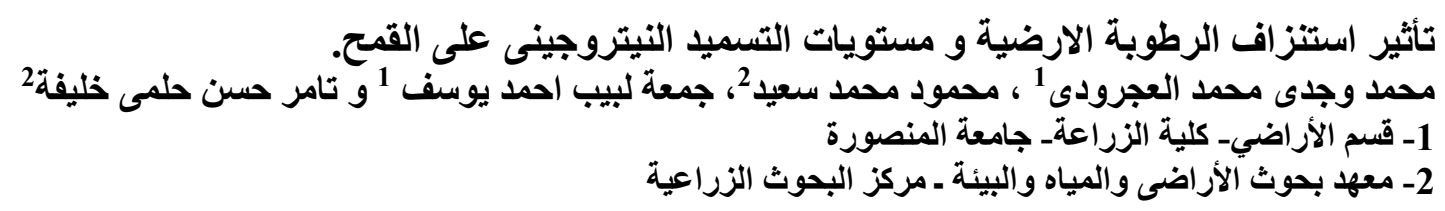

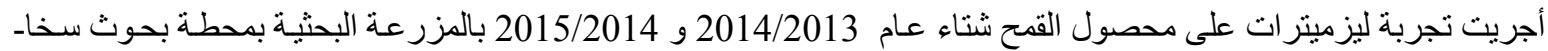

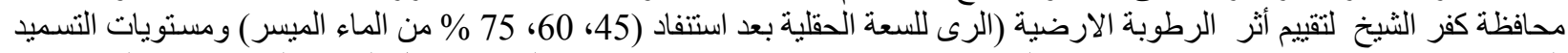

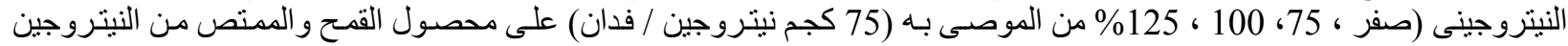
وكفاءة الاستخدام للماء و النيتروجين. وفيما يلي أهم النتائج المتحصل التخل عليها:

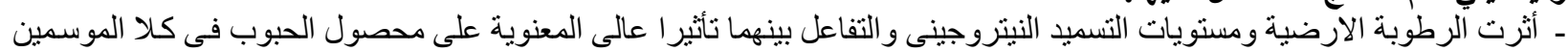

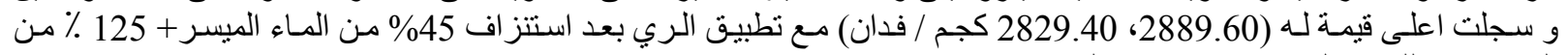
الموصى به للسماد النيتروجيني في كلا الموسمين.

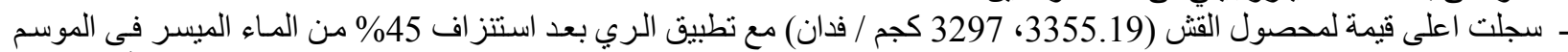

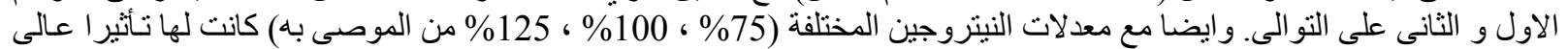

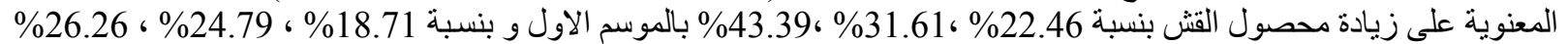

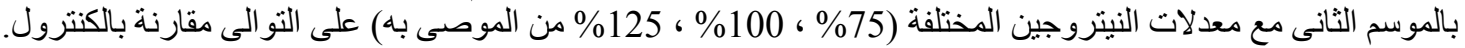

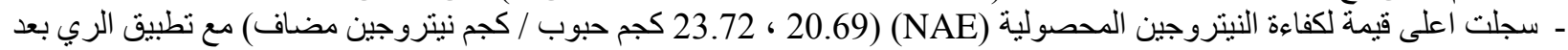

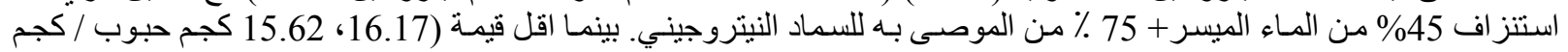

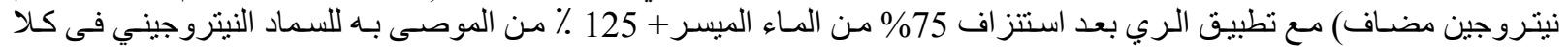
الموسمين.

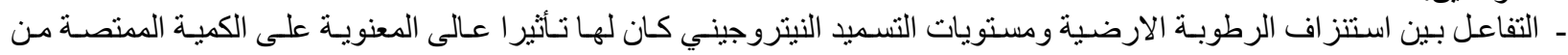

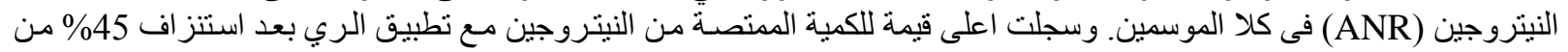

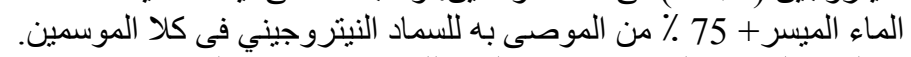

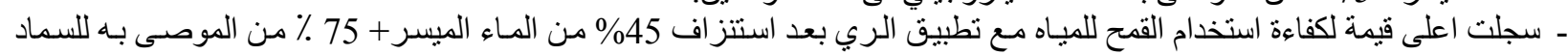

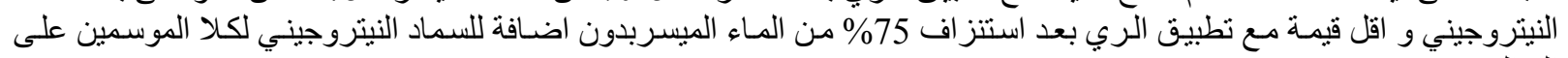
التو الى. 